\title{
Improvement axes identification for the components and the information flow of a hospital information system: A case Study
}

\author{
Sabrina Guetibi ${ }^{\# 1}$, Mohammed El Hammoumi ${ }^{\# 2}$ \\ ${ }^{*}$ Laboratory of industrial technics, Faculty of science and technics, Pole: \\ Information technology and Communication, systems and modelling, \\ University Sidi Mohammed Ben Abdellah, Road of Immouzer, B.P.2202, Fez, Morocco \\ ${ }^{1}$ sabrina.guetibi@gmail.com \\ 2m_elhammoumi@yahoo.fr
}

\begin{abstract}
Hospital Information System is the most fragile component of the health care system in the countries in development process. The modernization of the health care system does not integrate a rigid reflection on the installation of these tools into the hospital, which remain foreign with the strategies of these countries. This article aims at studying the case of a hospital Information system by schematizing the distribution of its components as well as its flow of information in the form of two complementary cartographies, a functional cartography and an information flow cartography, so this study's main objective is to reveal the axes of improvement of this system, by studying it, while focusing themselves on the transfer of information in the hospital institution which is the object of our study, to demonstrate this objective we have developed rich and flexible scenarios in the form of flowchart, that can also incorporate descriptions of users and their current and potential use of the information system. The formalization of the cartographies, in our case, enters in an improvement approach of the information system.
\end{abstract}

Keyword - Hospital Information System1, components2, functional cartography3, information flow artography4, Information System improvement5.

\section{INTRODUCTION}

The introduction of any change poses a certain number of problems and of resistance at various levels. In the field of the information systems in health the problematic of introduction, although being common to all the countries, seem to have a peculiarity in the African context [8]. Indeed, African hospitals are differentiated from several angles relating to the cultural, political, organizational and structural context of hospital institutions. The management of these aspects constitutes obviously, an additional challenge to raise for the implementation and management of computerized information systems [3].

The Hospital Information system is inserted in the organization "hospital" in perpetual evolution; it is able, according to rules and preset procedures, of acquiring data, evaluating it, processing it by computer or organizational tools, to distribute information containing a strong added value to all the internal or external partners of the establishment, collaborating in a common work directed towards a specific goal, namely the assumption of responsibility of a patient and the re-establishment of this one [4].

To reinforce this state of mind, it appeared important to us to describe the information system to measure the insufficiencies, to point the factors must reinforce to build in the second time a factual base of knowledge able to help the decision makers, clinicians and managers [10].

In this work, we will start with a case study of a Moroccan hospital, which is a university hospital center, the purpose of this study is to define the existing HIS, to know its characteristics, and to measure its level of maturity, to chart and schematize the existing system and to propose improvements, schematically, per the returns on the questionnaires and the remarks made during our study.

Lastly, the main aims of this study are, of one, to study the case of a Moroccan hospital institution of close, by implying the users in the study of the existing HIS, of two, try to propose improvements allowing to evolve the system per the organization evolutions and to the user needs.

\section{Methodology}

The organization which is the object of our study is a Moroccan hospital, and in order to study its IS, we used two questionnaires, the first, aimed at manager and responsible of IT department, was completed with the aim of defining the characteristics of the system; the second, aimed at the pilots of the HIS components, was in the form of a System Components Information Sheet (Modules). Our main objective is to study the state of the existing system, to have a sight on the level of maturity of this last, like arising the problems and difficulties pronounced during the use of the system, to propose improvements making it possible to make evolve the system according to the needs of its users and beneficiaries [7]. 
The best mode of answer to our principal question seemed to us to be pedagogical tool, of use simple and not very consuming time. This device was to make it possible to carry out both a diagnosis of the situation of the HIS. To have a complete view of the system and its components, we had recourse to the discussions with the IT staff, so we could make visits to the various services, which are using the HIS (laboratory, pharmacy, admission office)

To carry out the questionnaire of defining and diagnosing the system, we took as a starting point a diagnosis tool of the maturity of information systems [2], this tool is aimed at managers of medical-social institutions and services, who are managing one or more establishments/services. It can allow them:

- To analyse in an autonomous way maturity of their Information system current (level of cover, use, level of satisfaction)

- To obtain a first vision prioritized of the projects IS to carry out

- To evaluate the capacity to deploy a project IS

For the information sheets, we based ourselves on questions defining the functionalities of the modules of the system, as well as on the interactions [6] between the different modules and the type of information exchanged.

\section{A. Presentation of the studied HIS: Definition and diagnostic of the information system hospital of the hospital} institution

The collection of knowledge and information is carried out based on individual and collective interviews at the university hospital center. We have analysed the system to identify changes and improvements.

The definition in Table I and the diagnostic in Table II of the HIS of the university hospital center were made by referring to the persons in charge of informatics and statistical department, with the aim of determining the characteristics and the general information of the system and to provide information on its state and its maturity.

Table I gathers information defining the information system, in terms of objectives, components, and the functional perimeter...

TABLE I Definition of HIS

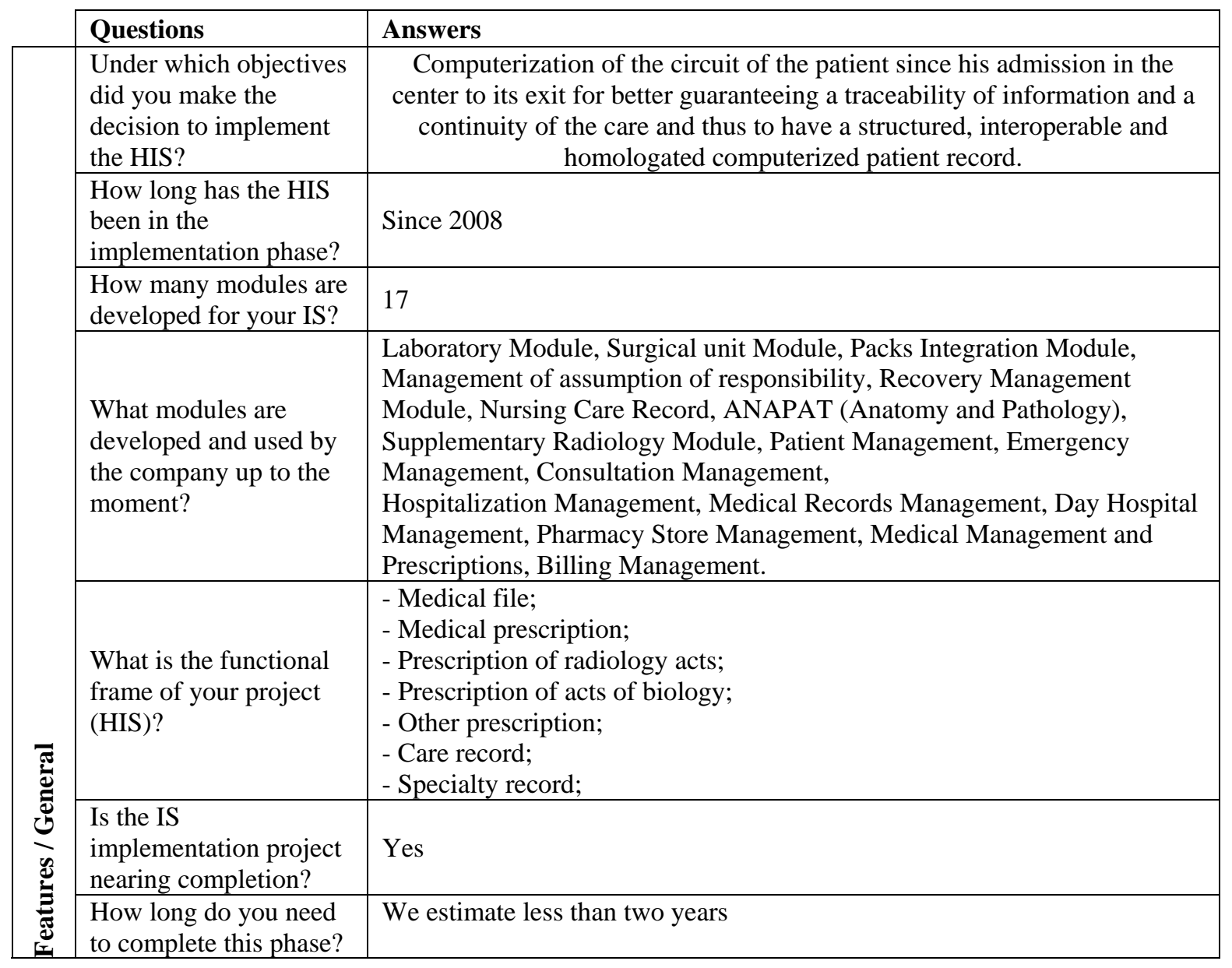


The following table provides a general diagnosis of the state of the existing HIS and its level of maturity, the answers to the questions presented below, gave us ideas on the nature of the questions to pose, staff to be questioned, possible sources of information, and ideas about encountered problems of the system ...; All this to bring out the necessary information concerning the components of the system.

TABLE II Diagnostic of HIS

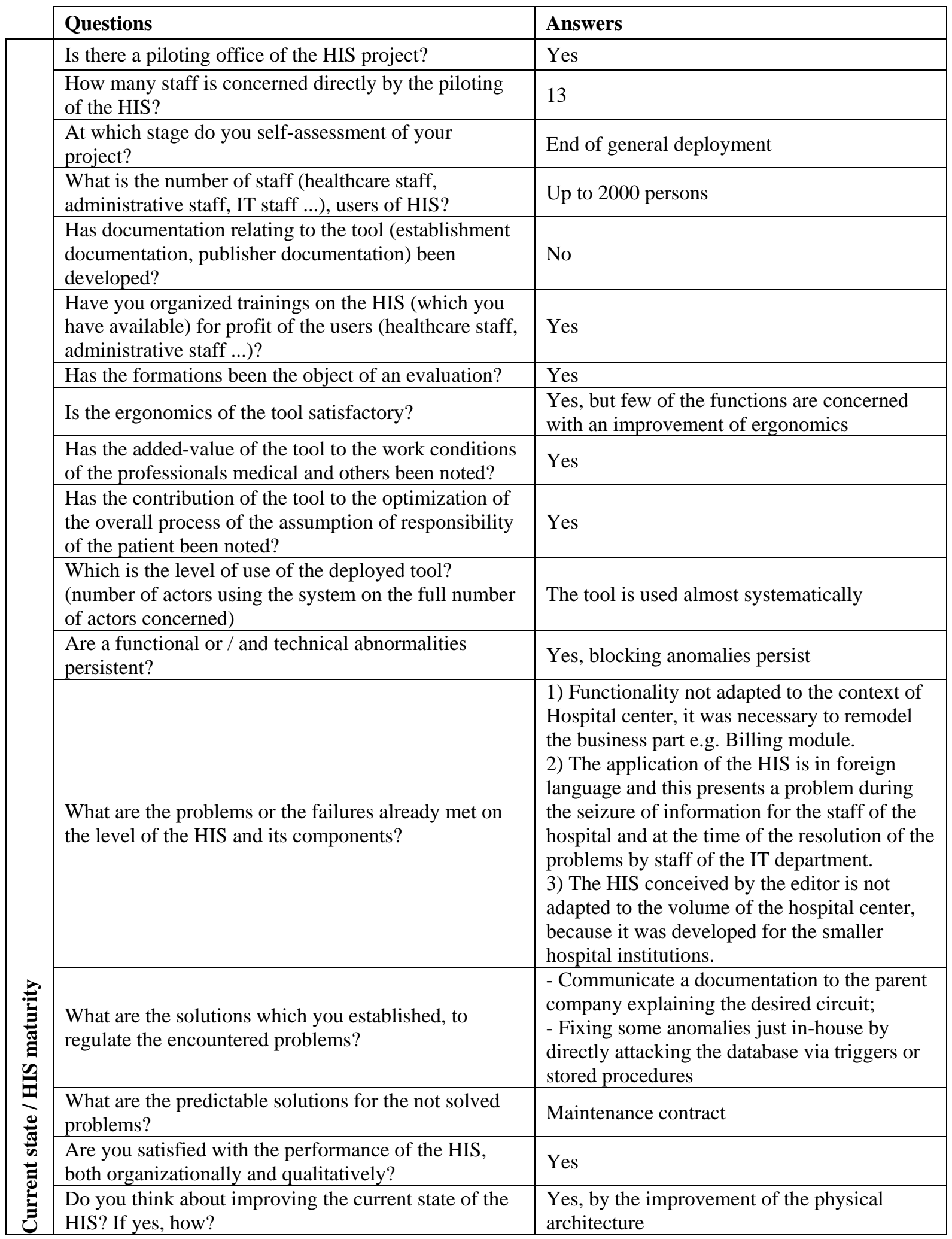




\section{B. $\quad$ Presentation of the sample}

In order to map the existing information system, by putting first the interactions between its modules, an information sheet on each module was disseminated to the IT and statistical service staff. These information sheets have the same questions for the various modules, each technician or engineer filled us the card of the module which it pilots.

Table III summarizes some information that defines each module. This information is gathered using the fact sheets presenting the following questions (two types of questions, open and with choices):

- General objective of design of the module (reason to be designed);

-Principal features of the module;

-Users \& beneficiaries of the module;

-Contributions (the output data of this module will be used for what?);

- Module and upstream processes (What modules that provide their output elements to be used as input data for this module?);

-Input data (information sheets, reports, results);

-Modules and downstream processes (What modules that will use the resulting output of this module as input data?);

- Output data (information, forms, reports, results);

- Observations and areas of progress (concerning module);

-What problems have already been encountered in the HIS and its components?

TABLE III Modules Definition of the Existing System

\begin{tabular}{|c|c|c|c|c|}
\hline Module & $\begin{array}{l}\text { General design } \\
\text { objective of this } \\
\text { module (reason to } \\
\text { be designed) }\end{array}$ & Module main features & $\begin{array}{l}\text { Users \& } \\
\text { beneficiaries of } \\
\text { the module }\end{array}$ & $\begin{array}{l}\text { Contributions (for } \\
\text { which reason the } \\
\text { output data of this } \\
\text { module will be } \\
\text { used?) }\end{array}$ \\
\hline $\begin{array}{l}\text { Operating } \\
\text { block module }\end{array}$ & $\begin{array}{l}\text { Need for } \\
\text { Traceability }\end{array}$ & $\begin{array}{l}\text { Know the duration of } \\
\text { operation, the duration of } \\
\text { occupation ... } \\
\text { Optimization of care } \\
\text { services, traceability of } \\
\text { data ... }\end{array}$ & $\begin{array}{l}\text { Doctor surgeon; } \\
\text { Doctor } \\
\text { anaesthetist }\end{array}$ & $\begin{array}{l}\text { Can produce } \\
\text { statistics } \\
\text { [By calculating: } \\
\text { Needs in terms of } \\
\text { medical equipment, } \\
\text { mortality rate ....] }\end{array}$ \\
\hline $\begin{array}{l}\text { Patient } \\
\text { Management }\end{array}$ & $\begin{array}{l}\text { Computerization of } \\
\text { Patient's path }\end{array}$ & $\begin{array}{l}\text { Creation of the patient } \\
\text { identifier "ID" (of which } \\
\text { the information will be } \\
\text { used for any future activity } \\
\text { within the hospital); } \\
\text { The patient ID number is } \\
\text { assigned automatically by } \\
\text { the system; } \\
\text { Thanks to the Permanent } \\
\text { Patient ID, the system can } \\
\text { trace the history of each } \\
\text { patient at the hospital } \\
\text { level. }\end{array}$ & $\begin{array}{l}\text { Doctors; } \\
\text { Secretaries; } \\
\text { Nurses; } \\
\text { Administrator }\end{array}$ & $\begin{array}{l}\text { Rapid access to the } \\
\text { patient history, to } \\
\text { the results and } \\
\text { appointment... }\end{array}$ \\
\hline $\begin{array}{l}\text { Consultation } \\
\text { Management }\end{array}$ & $\begin{array}{l}\text { Patient Relationship } \\
\text { Management } \\
\text { (Patient follow-up) }\end{array}$ & Organize appointments. & $\begin{array}{l}\text { Doctors; } \\
\text { Secretaries; } \\
\text { Patients. }\end{array}$ & $\begin{array}{l}\text { With this module, } \\
\text { one books a place } \\
\text { to the patients in } \\
\text { the diary to carry } \\
\text { out consultations } \\
\text { and specific } \\
\text { activities; } \\
\text { It makes it possible } \\
\text { to organize } \\
\text { information in a } \\
\text { Structured and } \\
\text { coherent. }\end{array}$ \\
\hline
\end{tabular}




\begin{tabular}{|c|c|c|c|c|}
\hline $\begin{array}{l}\text { Medical } \\
\text { Records } \\
\text { Management }\end{array}$ & $\begin{array}{l}\text { Computerization of } \\
\text { the patient's medical } \\
\text { record }\end{array}$ & $\begin{array}{l}\text { Manage the consultations; } \\
\text { See reports and } \\
\text { questionnaires at the } \\
\text { system level to facilitate } \\
\text { searches. }\end{array}$ & $\begin{array}{l}\text { Doctors; } \\
\text { Patients. }\end{array}$ & $\begin{array}{l}\text { Traceability of acts } \\
\text { for each patient; } \\
\text { Facilitate statistical } \\
\text { studies. }\end{array}$ \\
\hline $\begin{array}{l}\text { Day Hospital } \\
\text { Management }\end{array}$ & $\begin{array}{l}\text { It is a module } \\
\text { designed to create a } \\
\text { management tool for } \\
\text { patients hospitalized } \\
\text { for less than } 24 \\
\text { hours }\end{array}$ & $\begin{array}{l}\text { Perform the acts; } \\
\text { Organization of } \\
\text { consultations. }\end{array}$ & $\begin{array}{l}\text { Doctors; } \\
\text { Patients. }\end{array}$ & $\begin{array}{l}\text { This module makes } \\
\text { it possible to } \\
\text { facilitate work for } \\
\text { the doctor (to know } \\
\text { the consultations, } \\
\text { to know the } \\
\text { number of patients, } \\
\text { time slots...) }\end{array}$ \\
\hline $\begin{array}{l}\text { Laboratory } \\
\text { Module }\end{array}$ & $\begin{array}{l}\text { Managing and } \\
\text { editing balance } \\
\text { sheets }\end{array}$ & $\begin{array}{l}\text { Reception of the external } \\
\text { and internal balance sheet } \\
\text { requests; } \\
\text { Communication with } \\
\text { ILAB; } \\
\text { Editions of the results and } \\
\text { treatment of the anomalies } \\
\text { at the time of the reception } \\
\text { of the requests. }\end{array}$ & $\begin{array}{l}\text { Doctors; } \\
\text { Secretaries at } \\
\text { the laboratory } \\
\text { reception desk; } \\
\text { Laboratory } \\
\text { technicians; } \\
\text { Doctor } \\
\text { biologists; } \\
\text { Pharmacists; } \\
\text { Patients. }\end{array}$ & $\begin{array}{l}\text { Interpret diagnoses } \\
\text { regarding the } \\
\text { patient's condition } \\
\text { and suggest } \\
\text { appropriate } \\
\text { treatments; } \\
\text { Conduct statistical } \\
\text { studies on the } \\
\text { capacity of the } \\
\text { laboratory in terms } \\
\text { of treatment of the } \\
\text { analyses. }\end{array}$ \\
\hline $\begin{array}{l}\text { ANAPATH } \\
\text { folder } \\
\text { (anatomic- } \\
\text { pathology) }\end{array}$ & $\begin{array}{l}\text { Traceability; } \\
\text { Statistics; } \\
\text { rapidity and } \\
\text { readability of the } \\
\text { results by the doctor; } \\
\text { Accomplish the } \\
\text { patient file. }\end{array}$ & $\begin{array}{l}\text { Automation of daily work; } \\
\text { Systematic Billing } \\
\text { Rapidity and readability of } \\
\text { the results by the } \\
\text { prescribing doctor; }\end{array}$ & $\begin{array}{l}\text { Patients; } \\
\text { Doctors; } \\
\text { Laboratory } \\
\text { technician; } \\
\text { Resident } \\
\text { biologists; } \\
\text { Senior } \\
\text { biologists. }\end{array}$ & $\begin{array}{l}\text { Control the time of } \\
\text { exit of the results } \\
\text { by controlling the } \\
\text { time of the circuit } \\
\text { of the prescriptions } \\
\text { defined by doctor; } \\
\text { Can carry out the } \\
\text { instantaneous } \\
\text { invoicing of the } \\
\text { made analyses; } \\
\text { Can get out the } \\
\text { statistics at a given } \\
\text { time; } \\
\text { Carry out the } \\
\text { traceability helping } \\
\text { to research and the } \\
\text { extraction of } \\
\text { accurate } \\
\text { information and to } \\
\text { follow the history } \\
\text { of the patients. }\end{array}$ \\
\hline $\begin{array}{l}\text { Billing } \\
\text { Management }\end{array}$ & $\begin{array}{l}\text { Administrative } \\
\text { management of } \\
\text { patients; } \\
\text { Facilitate the real- } \\
\text { time integration of } \\
\text { information between } \\
\text { the operational (care } \\
\text { services) and the } \\
\text { decision-making } \\
\text { (Administration); } \\
\text { Traceability. }\end{array}$ & $\begin{array}{l}\text { Coding and valorisation of } \\
\text { acts; } \\
\text { Generating and editing } \\
\text { invoices. }\end{array}$ & $\begin{array}{l}\text { The admission } \\
\text { and Billing } \\
\text { Office; } \\
\text { The Recovering } \\
\text { cell; } \\
\text { The } \\
\text { Assumption of } \\
\text { responsibility } \\
\text { cell; } \\
\text { The } \\
\text { Administrative } \\
\text { persons in } \\
\text { charge on the } \\
\text { level as of }\end{array}$ & $\begin{array}{l}\text { Operational Side: } \\
\text { Communication in } \\
\text { real time between } \\
\text { administrative and } \\
\text { medical staff; } \\
\text { Administrative } \\
\text { Side: } \\
\text { *Aide with the } \\
\text { decision per the } \\
\text { exploitation of the } \\
\text { data of the } \\
\text { invoicing; } \\
\text { *Visibility of }\end{array}$ \\
\hline
\end{tabular}




\begin{tabular}{|c|c|c|c|c|}
\hline & & & services of care. & $\begin{array}{l}\text { expenditure of the } \\
\text { hospital; } \\
\text { *Justification near } \\
\text { the organizations of } \\
\text { Mutual insurance } \\
\text { (To facilitate } \\
\text { recovering near the } \\
\text { organizations). }\end{array}$ \\
\hline $\begin{array}{l}\text { Assumption } \\
\text { of } \\
\text { responsibility }\end{array}$ & $\begin{array}{l}\text { Management of the } \\
\text { files of assumption } \\
\text { of responsibility of } \\
\text { mutualist patients; } \\
\text { Traceability. }\end{array}$ & $\begin{array}{l}\text { To draw up the Sheet of } \\
\text { assumption of } \\
\text { responsibility; } \\
\text { To establish the estimates; }\end{array}$ & $\begin{array}{l}\text { Cell of } \\
\text { Assumption of } \\
\text { responsibility } \\
\text { (Accounting } \\
\text { Technicians). }\end{array}$ & $\begin{array}{l}\text { Define the } \\
\text { assumption of } \\
\text { responsibility of a } \\
\text { patient by an } \\
\text { organization per the } \\
\text { movement. }\end{array}$ \\
\hline $\begin{array}{l}\text { Recovery } \\
\text { Management }\end{array}$ & $\begin{array}{l}\text { Management of the } \\
\text { files of recovery; } \\
\text { Management of } \\
\text { dispatch slips; } \\
\text { _Traceability. }\end{array}$ & Sending invoices by slip. & $\begin{array}{l}\text { Recovery Unit } \\
\text { (Accounting } \\
\text { Technicians). }\end{array}$ & $\begin{array}{l}\text { Establish the } \\
\text { history of the } \\
\text { sending, } \\
\text { regulations or } \\
\text { rejections. }\end{array}$ \\
\hline Radiology & $\begin{array}{l}\text { Management of the } \\
\text { radiology } \\
\text { department; } \\
\text { Traceability of } \\
\text { radiological } \\
\text { procedures. }\end{array}$ & $\begin{array}{l}\text { Management of the pre- } \\
\text { appointments [starting } \\
\text { from the deposit of the } \\
\text { voucher (request for } \\
\text { analysis): the secretary } \\
\text { collects information on the } \\
\text { patients and their } \\
\text { diagnoses, thereafter the } \\
\text { doctor manages and } \\
\text { selected and gives the } \\
\text { APPOINTMENTS while } \\
\text { basing himself on the case } \\
\text { of each patient and the } \\
\text { availability of the devices]; } \\
\text { Management of } \\
\text { radiologists' calendars; } \\
\text { Optimization of the hourly } \\
\text { work load per day; } \\
\text { Management and } \\
\text { monitoring of the patient's } \\
\text { workflow [ the patient path } \\
\text { within the service of } \\
\text { radiology]; } \\
\text { Management of patient } \\
\text { reports [in progress, } \\
\text { corrected, signed, } \\
\text { delivered (either to the } \\
\text { patient or to the } \\
\text { hospitalization service)]; } \\
\text { Visualization of a patient's } \\
\text { images from the RIS } \\
\text { (Radiological Information } \\
\text { System); } \\
\text { Establish statistics on the } \\
\text { services performed and the } \\
\text { workload of doctors } \\
\text { Communication with } \\
\text { PACS servers. }\end{array}$ & $\begin{array}{l}\text { Secretaries of } \\
\text { reception; } \\
\text { Radiologists; } \\
\text { Redaction } \\
\text { Secretaries }\end{array}$ & $\begin{array}{l}\text { Have a visibility on } \\
\text { the workload by } \\
\text { agenda [each } \\
\text { medical device has } \\
\text { its agenda } \\
\text { (MRI, ...)], which } \\
\text { allows good } \\
\text { planning of other } \\
\text { appointments; } \\
\text { Statistics on } \\
\text { diagnoses } \\
\text { encountered in } \\
\text { services and cases } \\
\text { treated; } \\
\text { Reduction in the } \\
\text { rate of printing } \\
\text { (reduction of costs } \\
\text { and pollution); } \\
\text { Management of } \\
\text { time and material } \\
\text { resources. }\end{array}$ \\
\hline $\begin{array}{l}\text { Medical } \\
\text { Management } \\
\text { and }\end{array}$ & $\begin{array}{l}\text { Establish a } \\
\text { connection between } \\
\text { the module doctor }\end{array}$ & $\begin{array}{l}\text { Prescription of care; } \\
\text { Prescription of protocol } \\
\text { and prescription of }\end{array}$ & $\begin{array}{l}\text { Doctors; } \\
\text { Nurses. }\end{array}$ & $\begin{array}{l}\text { Know exactly the } \\
\text { drugs (time and } \\
\text { quantity) to be }\end{array}$ \\
\hline
\end{tabular}




\begin{tabular}{|c|c|c|c|c|}
\hline Prescriptions & $\begin{array}{l}\text { and the module male } \\
\text { nurse; } \\
\text { Mastery of the } \\
\text { divergences of the } \\
\text { drugs; } \\
\text { Limit the risks of } \\
\text { medical error. }\end{array}$ & $\begin{array}{l}\text { treatment; } \\
\text { Display of medicines to be } \\
\text { prescribed for a patient } \\
\text { directly on an external } \\
\text { application: Pyxis / } \\
\text { Medstation (local } \\
\text { pharmacy) at the level of } \\
\text { each service. }\end{array}$ & & $\begin{array}{l}\text { administered to a } \\
\text { patient; } \\
\text { Definition of } \\
\text { responsibilities in } \\
\text { case of medical } \\
\text { error. }\end{array}$ \\
\hline Nurse folder & $\begin{array}{l}\text { The nursing record } \\
\text { is one of the } \\
\text { components of the } \\
\text { patient folder; it was } \\
\text { designed to have a } \\
\text { complete medical } \\
\text { record gathering all } \\
\text { acts including } \\
\text { nursing. }\end{array}$ & $\begin{array}{l}\text { Organizing care and their } \\
\text { continuity; } \\
\text { Provide appropriate patient } \\
\text { care; } \\
\text { Coordinate actions } \\
\text { between different actors; } \\
\text { Record patient data and } \\
\text { measurements. }\end{array}$ & $\begin{array}{l}\text { Nurses; } \\
\text { Nurse chief; } \\
\text { Caregiver; } \\
\text { General } \\
\text { supervisor. }\end{array}$ & $\begin{array}{l}\text { To feed from other } \\
\text { modules of the } \\
\text { HIS, for example } \\
\text { the module of the } \\
\text { medical file, } \\
\text { module of the } \\
\text { administrative file, } \\
\text { nosocomial } \\
\text { infection module ... }\end{array}$ \\
\hline Pharmacy & $\begin{array}{l}\text { Inventory control of } \\
\text { the drugs and } \\
\text { fungible to supply } \\
\text { the Medstations } \\
\text { (stores on the level } \\
\text { of the services). }\end{array}$ & $\begin{array}{l}\text { Managing the circuit drug } \\
\text {-> patient; } \\
\text { Supply; } \\
\text { Order (as required by } \\
\text { hospital services); } \\
\text { Storage (stock (min / } \\
\text { max), order point ....); } \\
\text { Distribution to services. }\end{array}$ & $\begin{array}{l}\text { Preparers; } \\
\text { Pharmacists; } \\
\text { Nurses; } \\
\text { Patients. }\end{array}$ & $\begin{array}{l}\text { Prepare statistical } \\
\text { studies to make } \\
\text { decisions on future } \\
\text { supplies } \\
\text { (Preventions). }\end{array}$ \\
\hline $\begin{array}{l}\text { Emergency } \\
\text { Management }\end{array}$ & $\begin{array}{l}\text { It is a module } \\
\text { designed to create a } \\
\text { management tool for } \\
\text { patients entered in } \\
\text { case of emergency; } \\
\text { Management of the } \\
\text { relation with the } \\
\text { patients (Followed up } \\
\text { the patients); } \\
\text { Traceability. }\end{array}$ & $\begin{array}{l}\text { Organization of the } \\
\text { emergency service; } \\
\text { Description of the } \\
\text { emergency case. }\end{array}$ & $\begin{array}{l}\text { Doctors; } \\
\text { Preparers } \\
\text { Patients. }\end{array}$ & $\begin{array}{l}\text { This module } \\
\text { facilitates the work } \\
\text { for the doctors and } \\
\text { the preparers, in } \\
\text { terms of time and } \\
\text { management of } \\
\text { entry and exit of the } \\
\text { patient from the } \\
\text { emergency } \\
\text { department; } \\
\text { Preparation of } \\
\text { reports and } \\
\text { accounts; }\end{array}$ \\
\hline Hospitalization & $\begin{array}{l}\text { It is a module } \\
\text { designed to create a } \\
\text { management tool for } \\
\text { inpatients; } \\
\text { Patient Relationship } \\
\text { Management } \\
\text { (Followed up the } \\
\text { patients); } \\
\text { Traceability. }\end{array}$ & $\begin{array}{l}\text { Organization of the } \\
\text { hospitalization service; } \\
\text { Realization of acts; } \\
\text { Optimization of care } \\
\text { services, traceability of } \\
\text { data ... }\end{array}$ & $\begin{array}{l}\text { Doctors; } \\
\text { Patients. }\end{array}$ & $\begin{array}{l}\text { This module makes } \\
\text { easier the doctor } \\
\text { work (know the } \\
\text { number of } \\
\text { hospitalizations, the } \\
\text { number of empty } \\
\text { beds, the time } \\
\text { slots ...) } \\
\text { Preparation of } \\
\text { reports and } \\
\text { accounts; }\end{array}$ \\
\hline
\end{tabular}

Table IV and V present the problems and difficulties [8] pronounced by IT staff (during our study, by our own observations, and by responses from the pilots of the HIS modules), the problems are distributed on three levels [9], for each module presenting failures, the levels are the following:

- The strategic level, which corresponds to design problems;

- The tactical level that corresponds to the network use;

- Operational level which relates to piloting. 
TABLE IV Part 1. Problems and Difficulties of the Modules on Different Levels

\begin{tabular}{|c|c|c|c|c|}
\hline & \multicolumn{4}{|c|}{ Modules } \\
\hline t & Laboratory & ANAPATH folder & $\begin{array}{l}\text { Billing } \\
\text { Management }\end{array}$ & $\begin{array}{l}\text { Assumption } \\
\text { of } \\
\text { responsibility }\end{array}$ \\
\hline 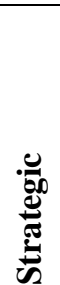 & $\begin{array}{l}\text { Achieving the } \\
\text { level of a system } \\
\text { of decision making } \\
\text { and management } \\
\text { of the diagnoses }\end{array}$ & $\begin{array}{l}\text { Modification requires } \\
\text { intervention by the } \\
\text { company (producer of the } \\
\text { system), which causes a } \\
\text { delay in solving the } \\
\text { problem }\end{array}$ & $\begin{array}{l}\text { Need for more } \\
\text { adaptation to the } \\
\text { hospital volume } \\
\text { and the Moroccan } \\
\text { context }\end{array}$ & $\begin{array}{l}\text { Need for } \\
\text { more } \\
\text { adaptation to } \\
\text { the hospital } \\
\text { volume and } \\
\text { the Moroccan } \\
\text { context }\end{array}$ \\
\hline 氖 & $\begin{array}{l}\text { Difficulties in } \\
\text { using }\end{array}$ & $\begin{array}{l}\text { Some technical failures that } \\
\text { do not satisfy the end user: } \\
\text { technical error, blockage of } \\
\text { an operation when filling } \\
\text { forms or reports ... }\end{array}$ & - & - \\
\hline 预 & $\begin{array}{l}\text { Reduce the rate of } \\
\text { anomalies; } \\
\text { Foreign language. }\end{array}$ & $\begin{array}{l}\text { Misuse of the system by the } \\
\text { end-user; } \\
\text { Foreign language. }\end{array}$ & Foreign language & $\begin{array}{l}\text { Foreign } \\
\text { language }\end{array}$ \\
\hline
\end{tabular}

TABLE V Part 2. Problems and Difficulties of the Modules on Different Levels

\begin{tabular}{|c|c|c|c|c|}
\hline & \multicolumn{4}{|c|}{ Modules } \\
\hline & $\begin{array}{l}\text { Recovery } \\
\text { Management }\end{array}$ & Radiology & $\begin{array}{l}\text { Medical Records } \\
\text { Management }\end{array}$ & Operating block module \\
\hline 氖 & $\begin{array}{l}\text { Need for more } \\
\text { adaptation to } \\
\text { the hospital } \\
\text { volume and the } \\
\text { Moroccan } \\
\text { context }\end{array}$ & $\begin{array}{l}\text { Reinforcement and } \\
\text { improvement of the } \\
\text { patient's visualization } \\
\text { parameters => add the } \\
\text { examination time, the } \\
\text { hours of inputs and } \\
\text { outputs and other } \\
\text { parameters allowing to } \\
\text { properly visualize the } \\
\text { patient path }\end{array}$ & - & $\begin{array}{l}\text { The module is not adapted } \\
\text { to the reality, because of } \\
\text { the additional information } \\
\text { requested, and there is a } \\
\text { lack of other information } \\
\text { necessary to mention }\end{array}$ \\
\hline 矛 & $\begin{array}{l}\text { Difficulties } \\
\text { in using }\end{array}$ & $\begin{array}{l}\text { Difficulties } \\
\text { in using }\end{array}$ & $\begin{array}{l}\text { Difficulties } \\
\text { in using }\end{array}$ & Difficulties in using \\
\hline 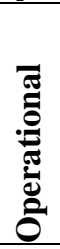 & $\begin{array}{l}\text { Foreign } \\
\text { language... }\end{array}$ & Foreign language & $\begin{array}{l}\text { Need for sensitizing of } \\
\text { the end-users } \\
\text { to have a traceability of } \\
\text { the data reliable and } \\
\text { exploitable. } \\
\text { Foreign language... }\end{array}$ & Foreign language \\
\hline
\end{tabular}

It remains to be mentioned that all the information system application is in foreign language (Spanish), so the operational problem in relation to the language used, is a problem present for all modules.

Our returns on the state of the computer equipment or IT infrastructure of the hospital are generally negative, The IT staff confirms that the number of computers, printers and means of communication (Tel, Fax) is weak compared to the need and the number of the users and staff of the hospital, and the estimate of the needs about server has not been solid because server capacity does not fully meet the requirements and volume of the hospital being studied. Despite all this we can't propose improvements in this regard, because we have not done a detailed study (statistics, which lists the number of each equipment), which will enable us to highlight action plans directly affecting the system infrastructure. Then our contribution will be on the functional level of the information system, and not directly on the physical architecture level. 


\section{III.RESULTS PRESENTATION}

Considering the information sheets of the various system modules, we have schematized the information system, what enabled us to reveal the connections between the modules, and to create a unified diagram, which considers the interactions between the various modules constituting the existing HIS. Those are two functional cartographies, describing the structuring of the information system into communicating functional blocks (first the existing system Fig.1, then the target system Fig.2 (after a reorganization of the existing system, a posteriori analysis and specification)), that's means the modules allowing to support business processes, by taking into account the dynamics of the processes, so that at the end having a cartography of flow of information (Fig.3) presenting the entries and the outputs of each module. Therefore, our goal is to present mesoscopic [9] cartographies and scenarios which incorporate the entities in the form of packages and constitutes an intermediate level between the macroscopic one and the microscopic one. Finally, it is to note that we realized these schemas using Edraw Max software (diagram software that makes it possible to create flow diagrams, network diagrams, building plans, scientific illustrations, UML diagrams, workflows, Directional maps and database diagram.).

We have demonstrated our work by presenting possible scenarios in an easy form to read, consisting of multiple steps, for our case those scenarios are constituted by several activities describing their steps without considering the time notion, to define those scenarios we used to present them into flowcharts of our final Information system. We preferred to build our scenarios in a form of flowchart, which is easy to follow and it's more representative, and this is the main objective of a scenario, as mentioned by Carroll [5] as definition: "The defining property of a scenario is that it projects a concrete description of activities that the user engages in when performing a specific task, a description sufficiently detailed so that design implications can be inferred and reasoned about. Using scenarios in system development helps keep the future use of the envisioned system in view as the system is designed and implemented; it makes use concrete - which makes it easier to discuss use and to design use.”

We have built our scenarios, as shown in Fig.4 to 12 based on the cartographies, questionnaires and our proper experience inside the Hospital.

The table below presents a reading key for all the schemas (cartographies and scenarios).

TABLE VI Reading Key and Icon Designation of the HIS Schemas

\begin{tabular}{|c|c|c|c|}
\hline Icons & Definition & Icons & Definition \\
\hline & Entrance & & Database \\
\hline & Exit & & Sub-module \\
\hline & Module & I \& $\mathrm{O}$ & $\begin{array}{c}\text { Input \& Output } \\
\text { e.g. 3I , O means } 3 \\
\text { inputs and one output }\end{array}$ \\
\hline 1 & $\begin{array}{c}\text { Succession of steps; } \\
\text { Succession of Steps } \\
\text { Mentioned in Other } \\
\text { Scenarios }\end{array}$ & & Incoming data \\
\hline $\left.\begin{array}{l}\cdots-\cdots \\
\vdots \\
\vdots\end{array}\right]-\cdots$ & Module distribution & & Outgoing data \\
\hline & Decision & & Document \\
\hline & Data & & $\begin{array}{l}\text { Preparation inside the } \\
\text { module: sub-activity }\end{array}$ \\
\hline
\end{tabular}




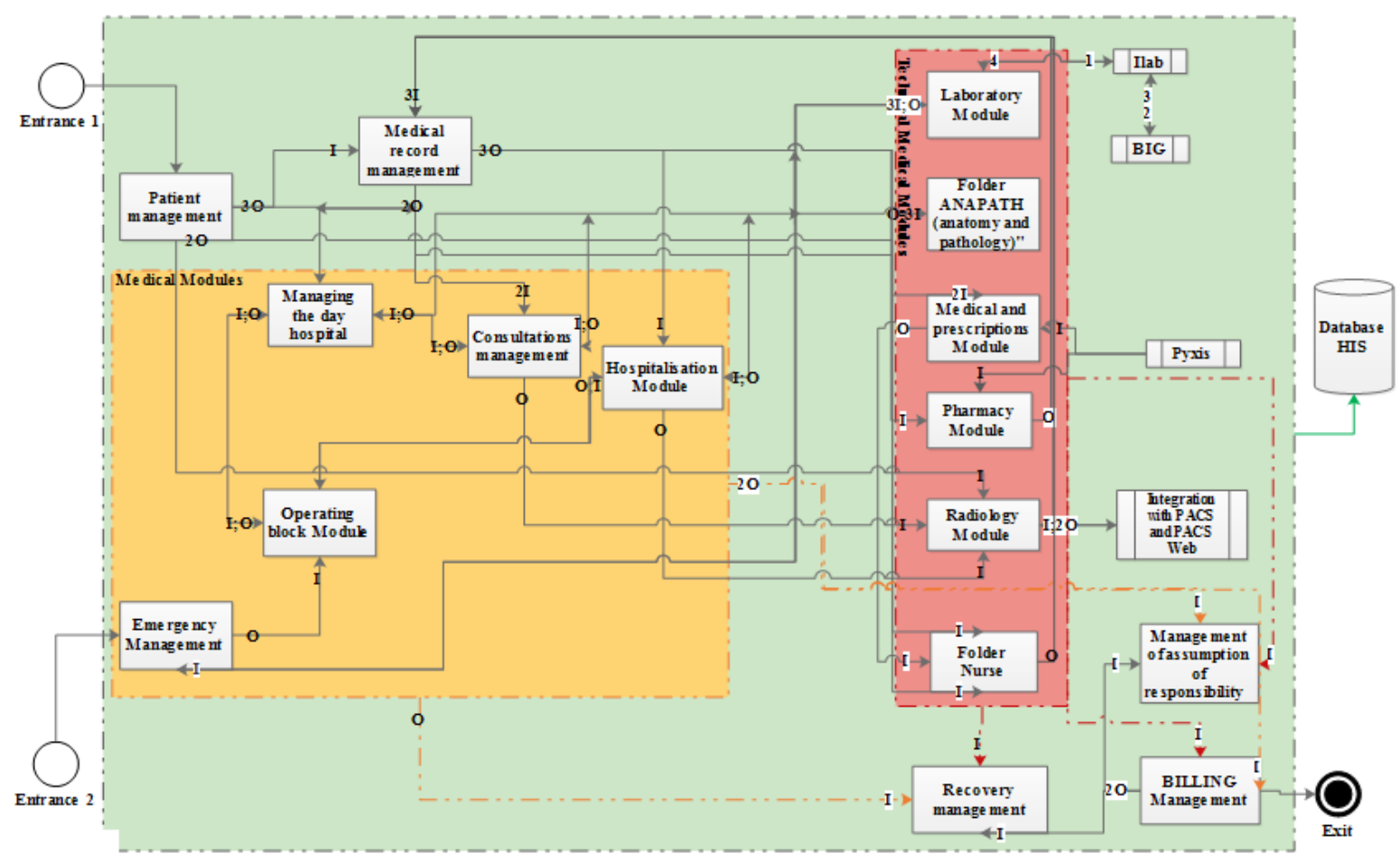

Fig. 1. Functional cartography of the existing HIS

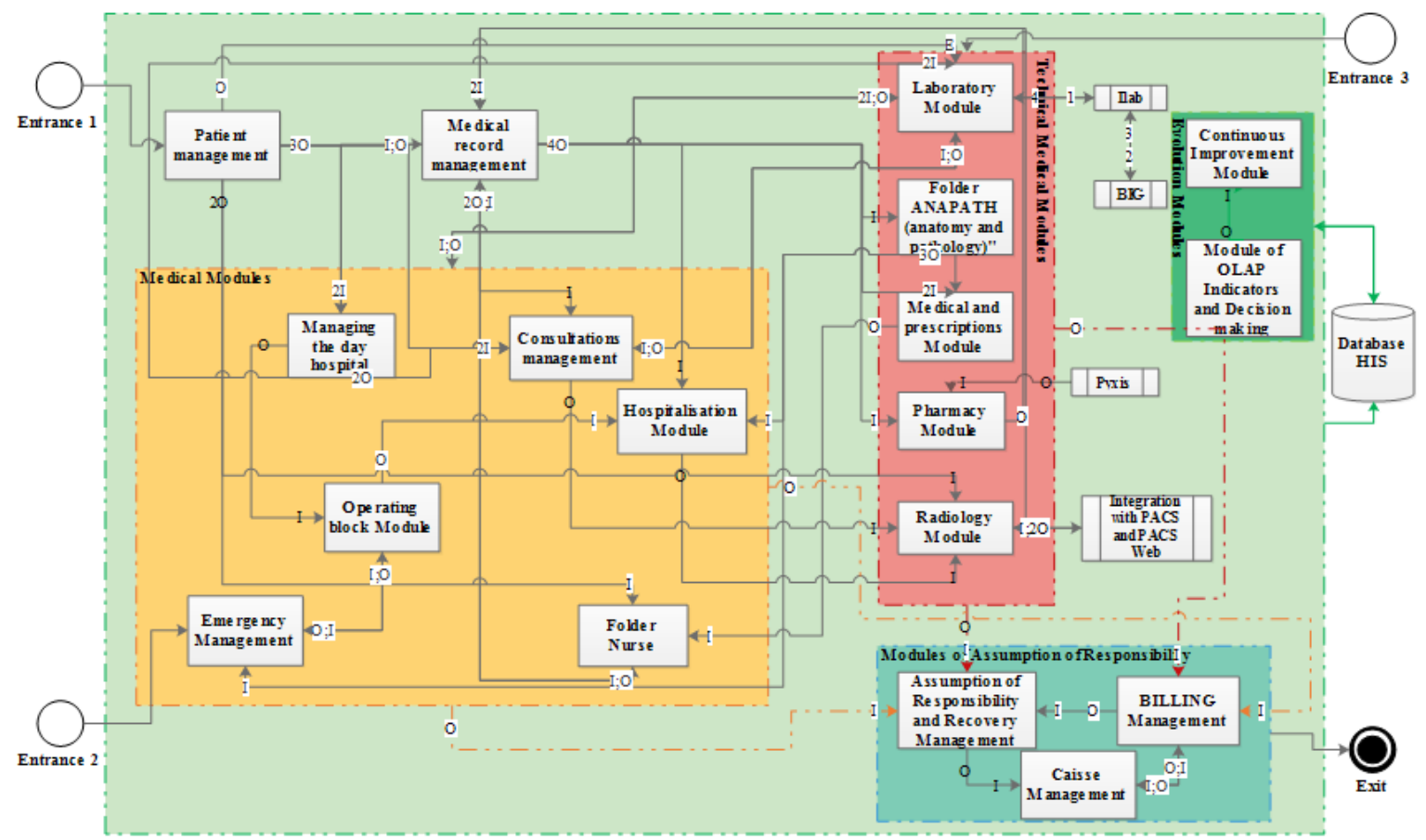

Fig. 2. Functional cartography of the HIS after distribution and improvement 


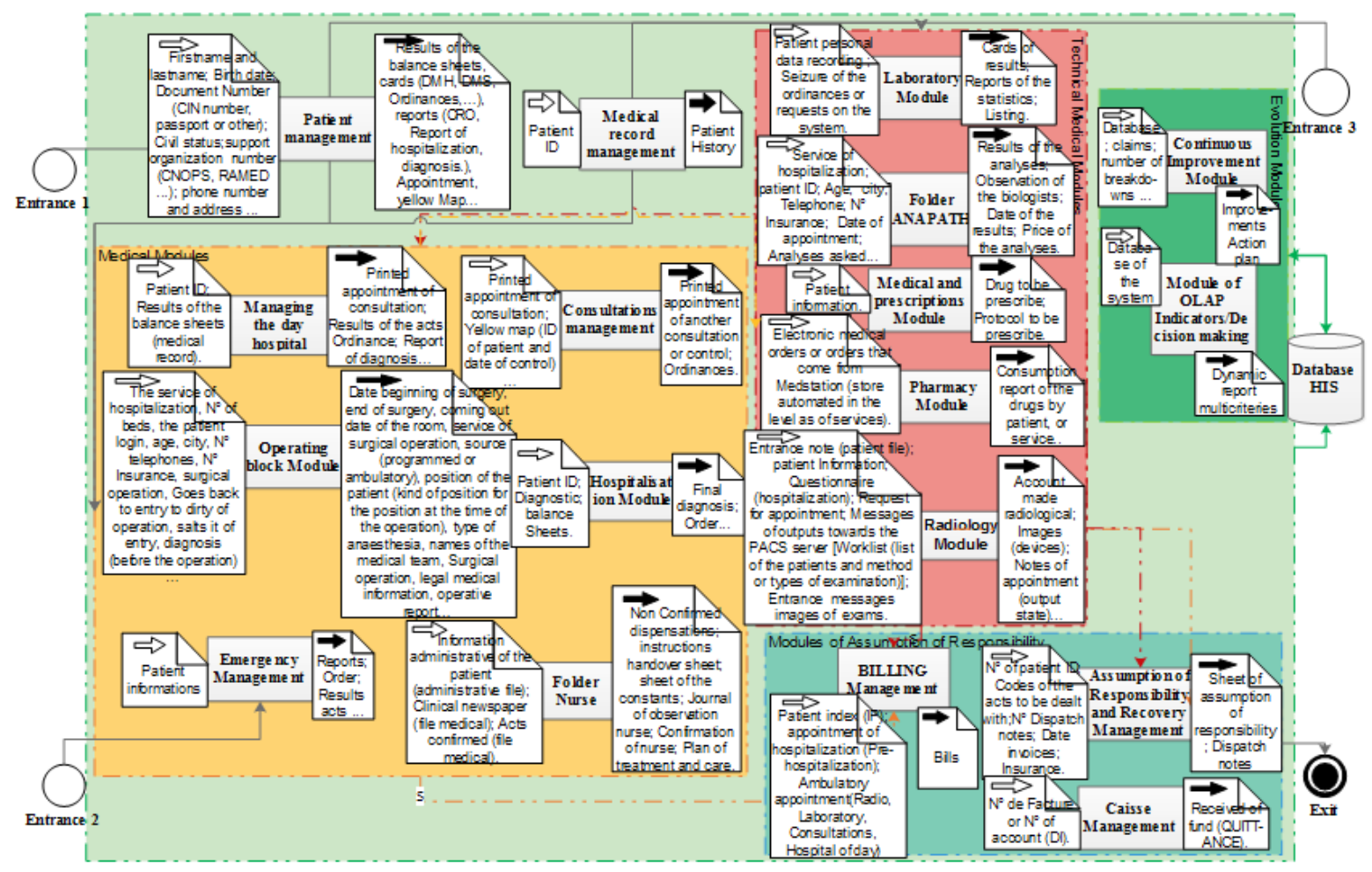

Fig. 3. Cartography of information flows of the new HIS

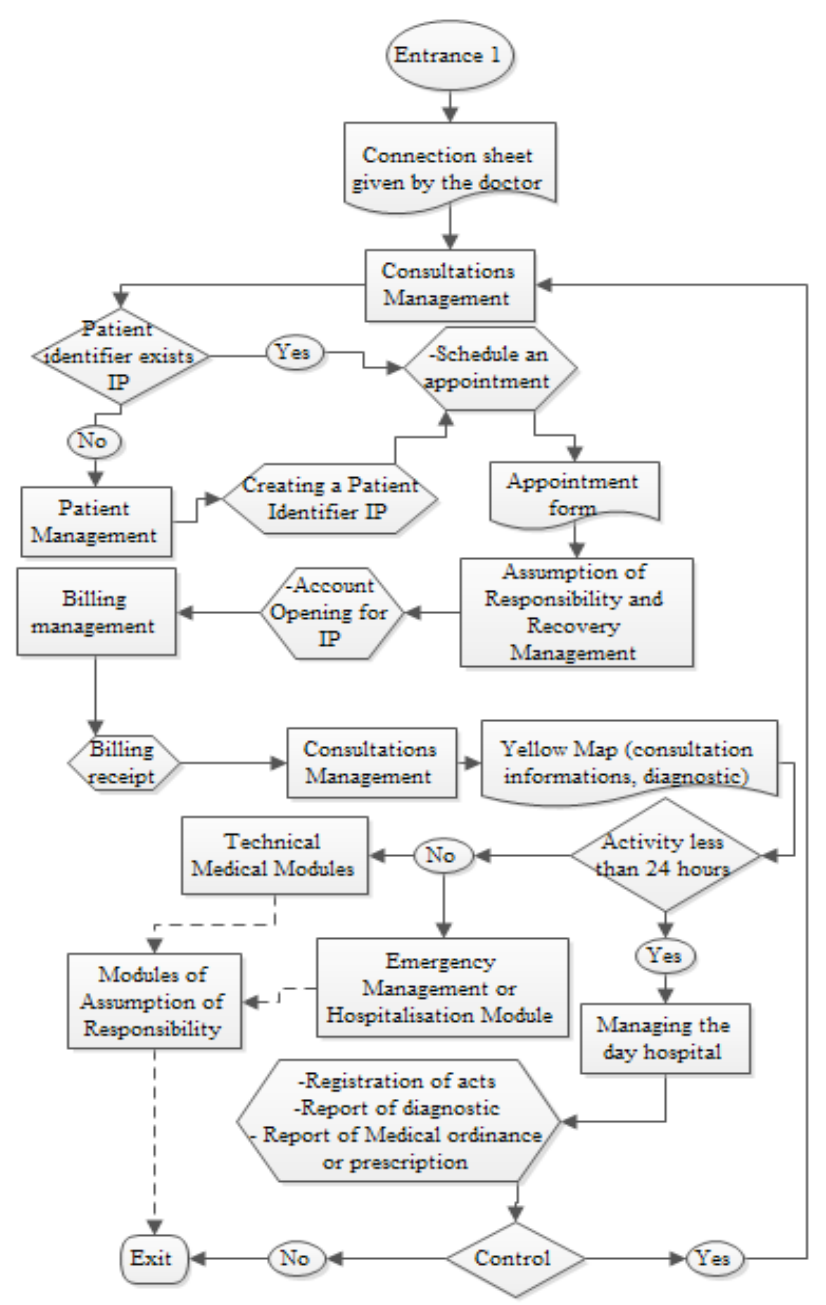

Fig. 4. Scenario A which the trigger module is the Consultation management 


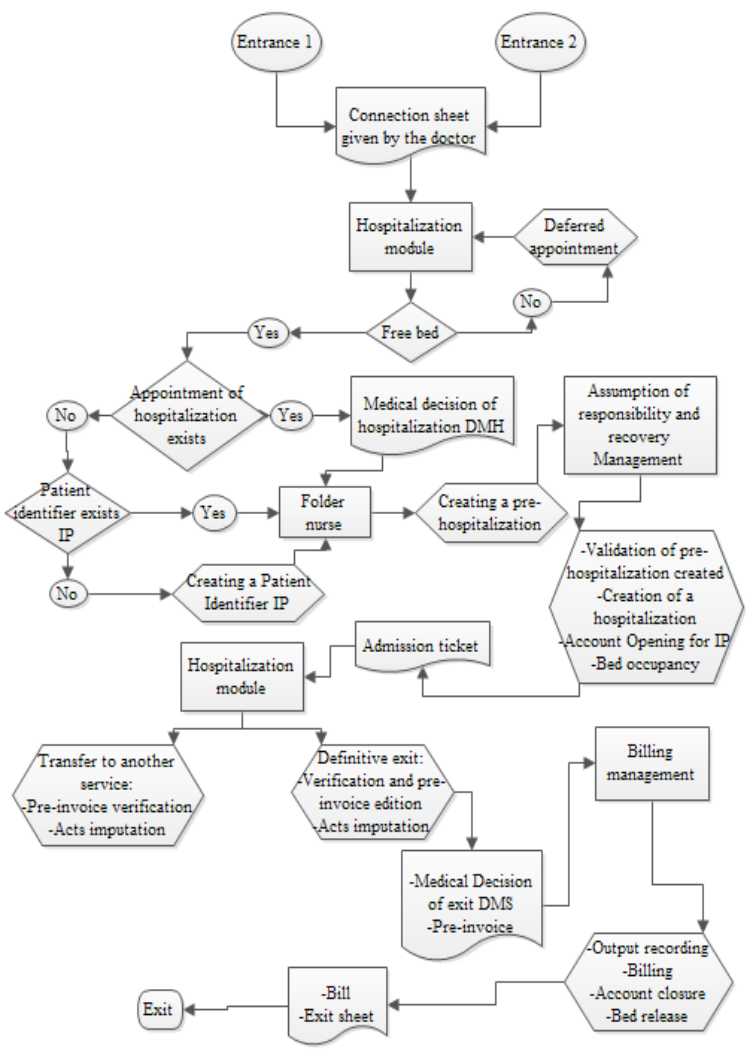

Fig. 5. Scenario B, which the trigger module is the Hospitalization Module

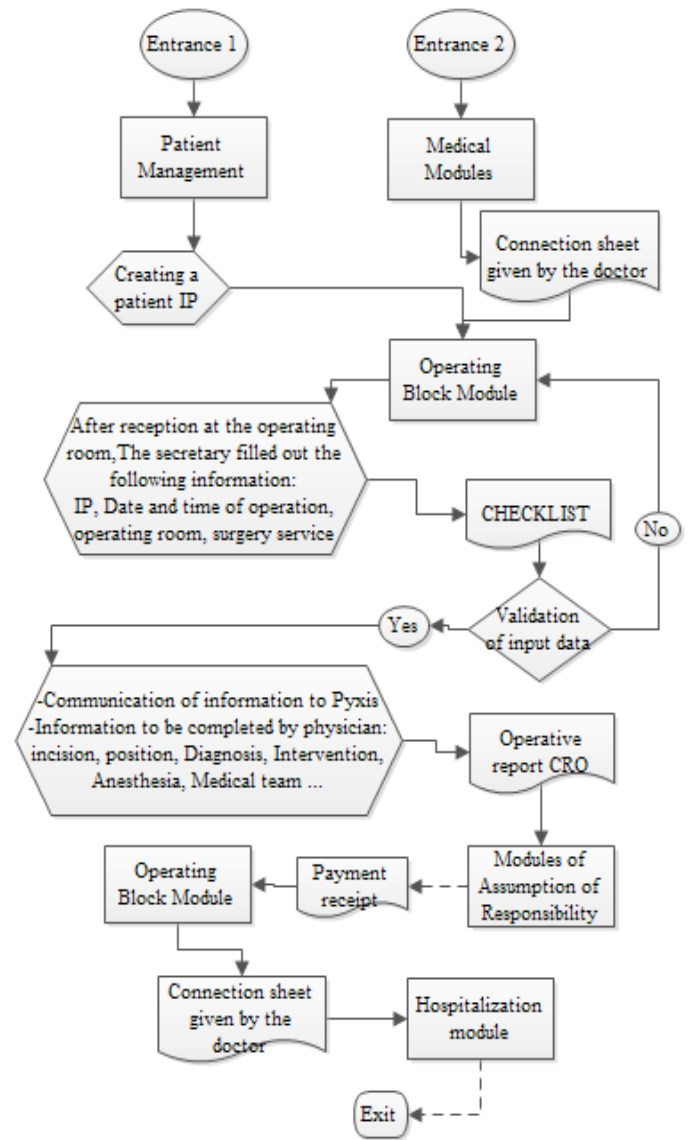

Fig. 6. Scenario C, which the trigger module is the Operating Block Module 


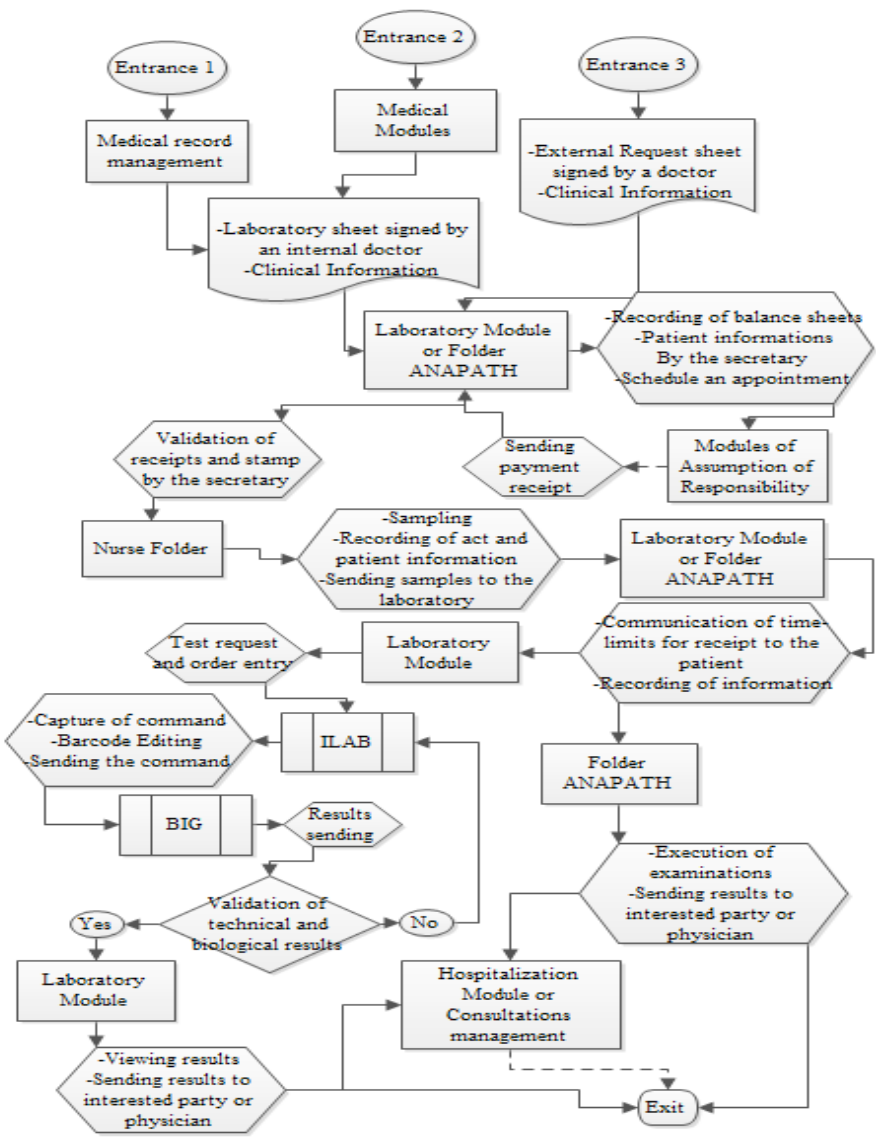

Fig. 7. Scenario D, which the trigger modules are the Laboratory Module and the Folder ANAPATH

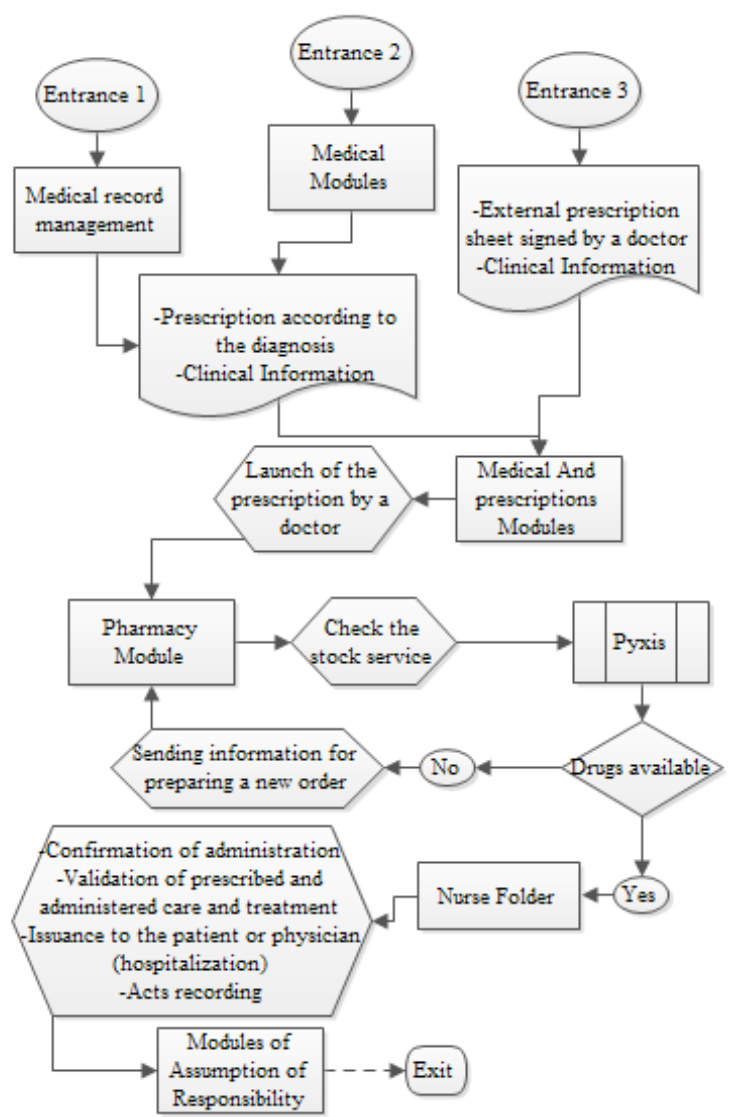

Fig. 8. Scenario E, which the trigger module is the Medical and prescription Module 


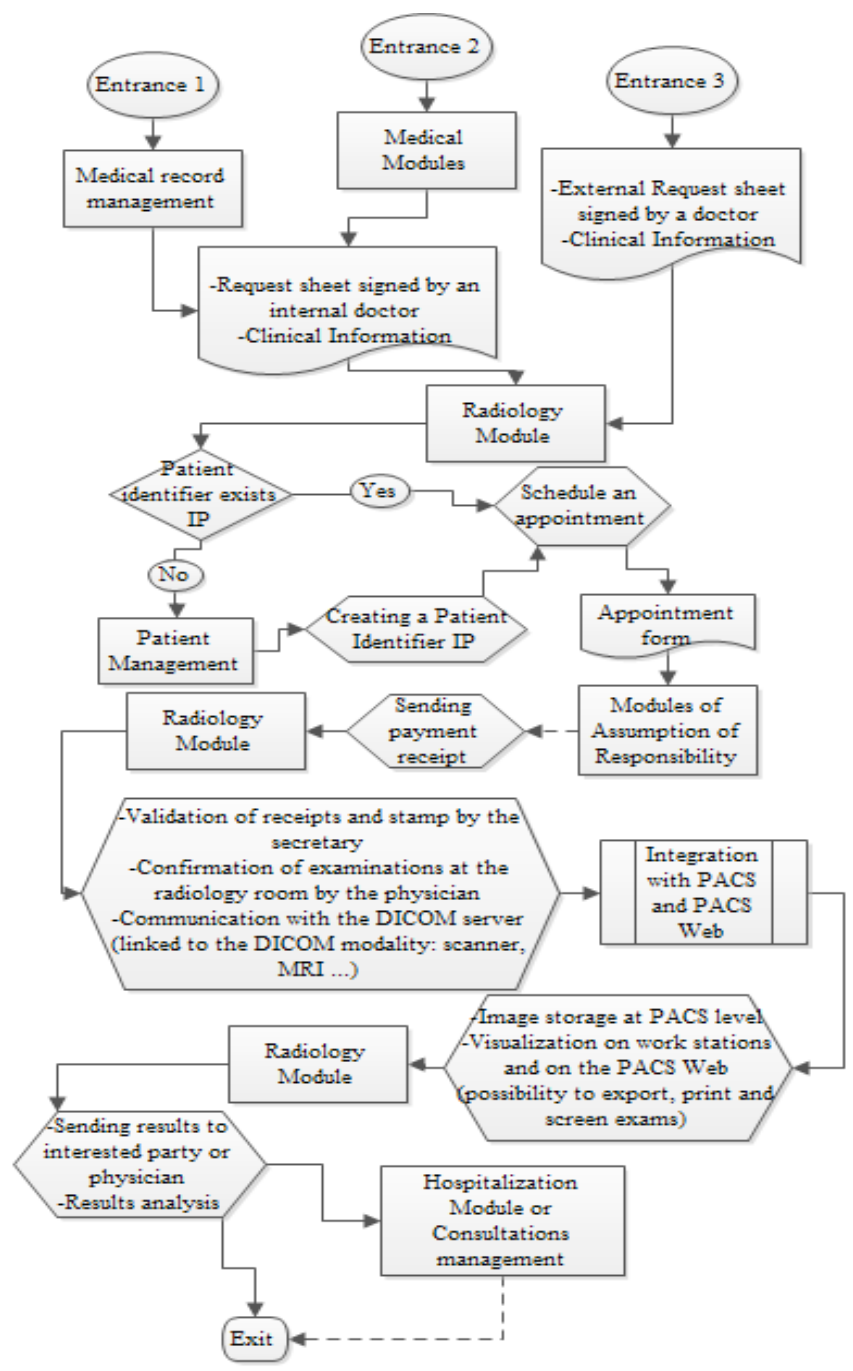

Fig. 9. Scenario F, which the trigger module is the Radiology Module

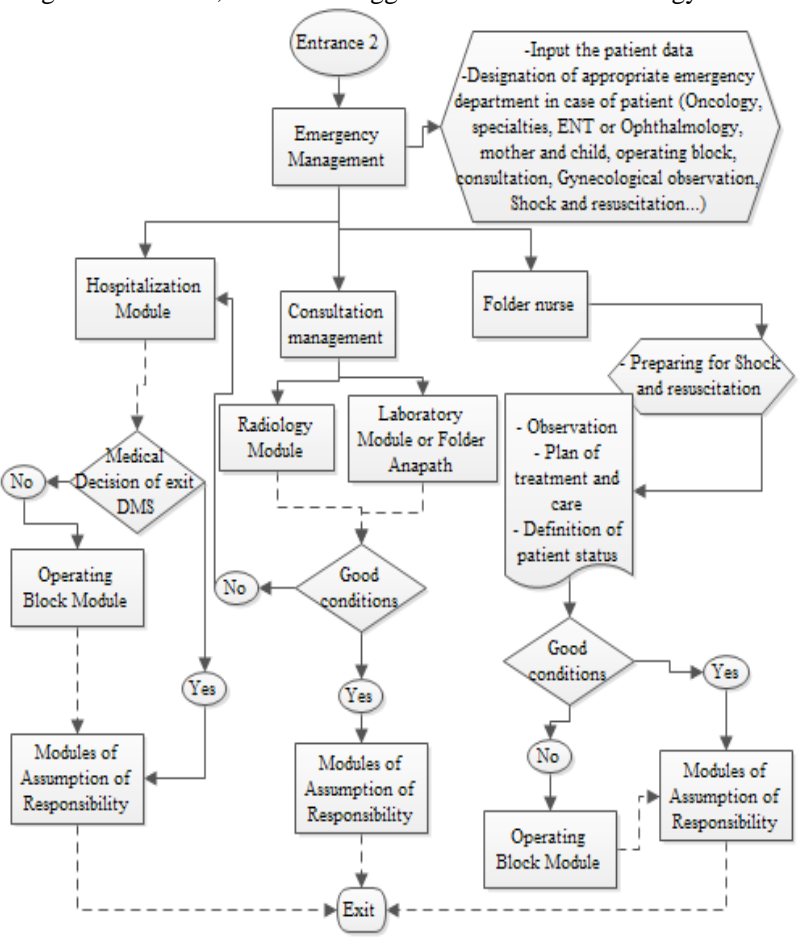

Fig. 10. Scenario G, which the trigger module is the Emergency Management 


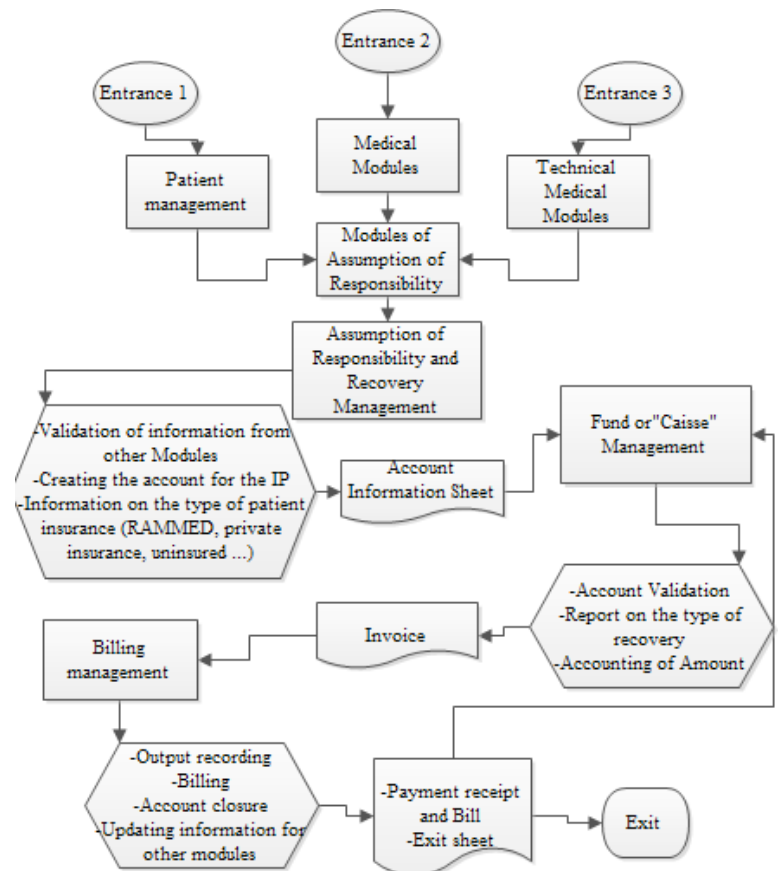

Fig. 11. Scenario H, which the trigger modules are the Modules of Assumption of Responsibility

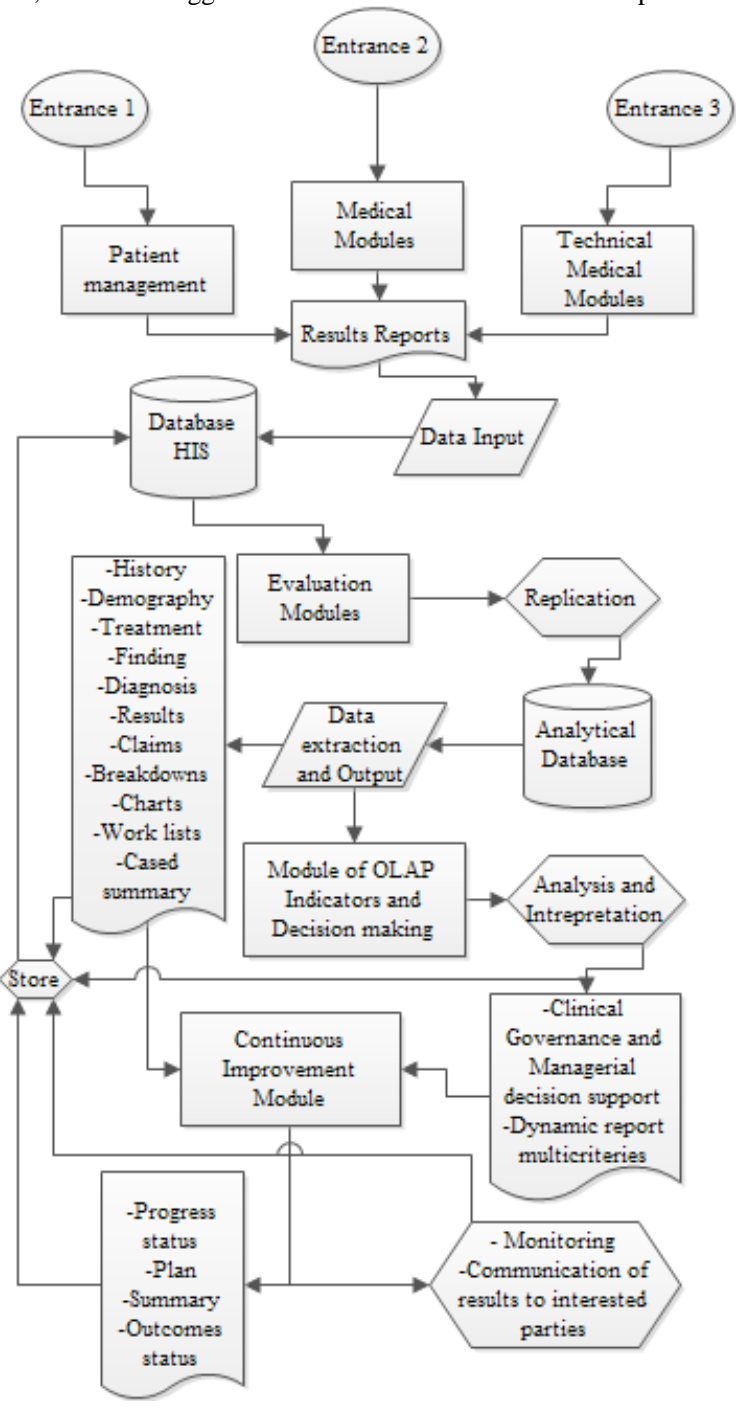

Fig. 12. Scenario I, which the trigger element is the Database 


\section{IV.ANALYSIS AND RESULTS DISCUSSION}

Whatever the studied models, that they act of applications dedicated to a problem given on the HIS or of an overall methodology, the design and the piloting of the HIS consist in determining the structure and the means which compose it, i.e., of making an analysis and specification, it is what we adopted like method at the time of our study.

Among the internal components of the existing HIS, as shown in Fig. 1 and of any system the database layer consisting of a database management system. This layer allows the access and the storage of the necessary data to the tools belonging to the different layers of the environment. Our contribution on this level is related to the exploitation of the database, we know all that information untreated does not have any sense, it is for that we thought to add two modules: module of continuous improvement and module Indicators OLAP and decision making.

Table VII presents the components added or modified in the functional cartography of the target HIS, as shown in Fig. 2, these components are presented in the same way as the modules grouped previously in Table III, presenting the module, its design objective, Its features or functionality, the users and its contributions for the HIS and the hospital institution.

TABLE VII Definition of modules added to the target system

\begin{tabular}{|c|c|c|c|c|}
\hline Module & $\begin{array}{l}\text { General design } \\
\text { objective of this } \\
\text { module (reason to be } \\
\text { designed) }\end{array}$ & $\begin{array}{l}\text { Module main } \\
\text { features }\end{array}$ & $\begin{array}{l}\text { Users \& } \\
\text { beneficiaries } \\
\text { of the module }\end{array}$ & $\begin{array}{l}\text { Contributions (for which } \\
\text { reason the output data of } \\
\text { this module will be } \\
\text { used?) }\end{array}$ \\
\hline $\begin{array}{l}\text { OLAP } \\
\text { indicators and } \\
\text { decision- } \\
\text { making }\end{array}$ & $\begin{array}{l}\text { It is a module of } \\
\text { decisional Data } \\
\text { processing for } \\
\text { Management; } \\
\text { To have an overall } \\
\text { picture on the hospital } \\
\text { management } \\
\end{array}$ & $\begin{array}{l}\text { Multi-criteria } \\
\text { dashboard; }\end{array}$ & $\begin{array}{l}\text { Head of } \\
\text { services; } \\
\text { Hospitals } \\
\text { Directors. }\end{array}$ & $\begin{array}{l}\text { Making decisions about } \\
\text { management (business } \\
\text { process, management } \\
\text { systems, HIS...) }\end{array}$ \\
\hline $\begin{array}{l}\text { Fund or } \\
\text { "Caisse" } \\
\text { management }\end{array}$ & $\begin{array}{l}\text { Computerization of the } \\
\text { cashing to the fund; } \\
\text { _Traceability. }\end{array}$ & $\begin{array}{l}\text { Cashing; } \\
\text { Report of case } \\
\text { (Daily, } \\
\text { Monthly). }\end{array}$ & $\begin{array}{l}\text { Cashiers; } \\
\text { Stage } \\
\text { Manager. }\end{array}$ & Revenue statistics. \\
\hline $\begin{array}{l}\text { Assumption of } \\
\text { responsibility } \\
\text { \& recovery } \\
\text { management }\end{array}$ & $\begin{array}{l}\text { Management of the } \\
\text { files of assumption of } \\
\text { responsibility of the } \\
\text { mutualists patients; } \\
\text { Management of the } \\
\text { recovery files; } \\
\text { Management of } \\
\text { sending slips; } \\
\text { Traceability. }\end{array}$ & $\begin{array}{l}\text { Draw up the } \\
\text { Sheet of } \\
\text { assumption of } \\
\text { responsibility; } \\
\text { Establish the } \\
\text { estimates; } \\
\text { Sending of the } \\
\text { invoices by } \\
\text { slips. }\end{array}$ & $\begin{array}{l}\text { Unit of } \\
\text { assumption of } \\
\text { responsibility } \\
\text { and recovery } \\
\text { unit } \\
\text { (countable } \\
\text { Technicians) }\end{array}$ & $\begin{array}{l}\text { Define the assumption of } \\
\text { responsibility of a patient } \\
\text { by an organization } \\
\text { according to movement; } \\
\text { Establish the history of the } \\
\text { sending, regulations or } \\
\text { rejections. }\end{array}$ \\
\hline $\begin{array}{l}\text { Continuous } \\
\text { improvement }\end{array}$ & $\begin{array}{l}\text { Evolutions } \\
\text { management; } \\
\text { Have a general sight on } \\
\text { the problems and the } \\
\text { ideas posed by staff; } \\
\text { Traceability of the } \\
\text { action plans; } \\
\text { Guarantee the internal } \\
\text { communication. }\end{array}$ & $\begin{array}{l}\text { Claim box; } \\
\text { Ideas Box; } \\
\text { Monitoring of } \\
\text { action plans. }\end{array}$ & $\begin{array}{l}\text { Hospitals } \\
\text { Directors; } \\
\text { Unit Directors. }\end{array}$ & $\begin{array}{l}\text { Monitor the evolutions of } \\
\text { the systems (HIS, QMS, } \\
\text { RMS ...) compared to the } \\
\text { organization; } \\
\text { Form a basis of return to } \\
\text { the experiment; } \\
\text { Validate the decisions } \\
\text { taken in relation to the } \\
\text { management. }\end{array}$ \\
\hline
\end{tabular}

The HIS changes can be grouped into 4 themes:

- A different structure: in addition to the old distribution of modules, we will have a subsystem made up of the modules dedicated to the assumption of responsibility of the patient, and another subsystem made up of modules dedicated to the evolution of the management systems;

- Introduction of new technologies: Intranet, virtual boxes for ideas and for claims ... use of a pneumatic system for the distribution of medicines, balance sheets or analyzes (HIS flowchart with information flow);

- A search for rationalization of flows: no unit of care will be present among the medical-technical modules; 
- A different management of evolution: with the introduction of new rules of management like the modules of evolution.

Speaking of the maturity level of the existing information system, and since we are based on the "ANAP" guide [2], for the design of our questionnaire, Linked to the general diagnosis and maturity level of the system, we must say that according to the five maturity levels defined by ANAP [1], as shown in Table VIII , The existing HIS is in the third maturity level, Because at this level practices are standardized and adapted with mastery of the internal repository as well as a centralization of knowledge and practices where the organization has a strategic plan as well as a planning of the process improvements.

Speaking now of the HIS after modification and improvement we can conclude that the latter can be at the 4th level of maturity, because using the new system the organization will be able to measure qualitatively and quantitatively the objectives of the project and to adjust them.

TABLE VIII The five levels of maturity per "ANAP"

\begin{tabular}{|l|l|}
\hline Level 1 & $\begin{array}{l}\text { The general objectives of accompanying adapted to the context and the } \\
\text { accepted population are not formalized }\end{array}$ \\
\hline Level 2 & $\begin{array}{l}\text { The general objectives are specified and broken down into operational } \\
\text { objectives at the structural level }\end{array}$ \\
\hline Level 3 & $\begin{array}{l}\text { The operational objectives give rise to an action plan implemented at the } \\
\text { structural level }\end{array}$ \\
\hline Level 4 & $\begin{array}{l}\text { A policy of continuous improvement is organized and implemented } \\
\text { (multidisciplinary analysis of the actions implemented and improvement } \\
\text { plan deployed) }\end{array}$ \\
\hline Level 5 & $\begin{array}{l}\text { The impact of the policy of continuous improvement of benefits is } \\
\text { identified and measured }\end{array}$ \\
\hline
\end{tabular}

From another point of view of the WHO [11] and per the Capability Maturity Model (CMM), the maturity level found for the existing HIS can be parallel to Level 3 of the CMM, which is the level defined where the process is defined/confirmed as a standard business process, as well as the HIS level after modification can be parallel to level 4, which is Managed, this level when the process is managed per the metrics described in level 3, that is, data collection and analysis.

According to the two functional cartographies we can say that the detailed analysis of the results shows that existing cartography (Fig.1) is not satisfactory from an organizational point of view because it does not make it possible to view the connections between the modules, which can cause communication problems. Indeed, the organization of the existing HIS required the distribution of the modules in the form of packs for better visibility and to form solid links between the modules and sub-systems of the HIS.

Target cartography (Fig.2) of the HIS makes it possible to obtain a 100\% rate of interaction between the units (unit of the care, unit of supports and unit of management), 100\% of the orders and flows are assured, while allowing the maximum of connections between modules, to get closer to the reality of the hospital institution (which is a complex socio-technical system). In addition, the new cartography makes it possible to ensure a positive evolution and an improvement of the HIS, by exploiting the database (which did not have outputs for the existing HIS).

The third cartography, of information flows (Fig.3), is made while being based on the functional cartography of the target system, to have a general sight which gathers the various components of the existing system, besides the components added or modified in the second cartography.

Our goal was, thereby, to develop rich and flexible scenarios and concepts that can incorporate descriptions of users and their current and potential use of the information system. As a schematic description of what users do and experience when using this system, scenarios are such rich description of the human activities that can augment the comprehension of the system and present a simple demonstration of our work, the scenarios above (Fig.4 to 12), in the form of flowchart, were developed based on the cartography of information flows of the new HIS and the most frequently encountered task lists of the system.

Finally, we should say that this system must be technically approved, that is why we intend in future work to make an application of the latter, to ensure the smooth functioning of the improvements made. 


\section{CONCLUSION AND FUTURE WORK}

The system that we studied at the time of this research allows the automation of the statement of the constants and of the care; it is a little an improved "placard".

The use of this system by the staff, contributes to the improvement of the quality of the care by influencing certain factors like the security, the efficiency, the saving of time. It is possible to computerize the care process, planning care, always with the aim of improving the quality of care, this also saves time and increases safety, but this type of system allows the collection of precise and reliable information on the activities of hospitals.

The computerization of the care approach, of the care planning, the transitions will thereby play a primordial role in the evaluation of the practices of the hospital institutions and thus on the improvement of the care quality. Improving the quality of care does not only depend on its assessment but also on a regular contribution of knowledge, a handing-over in question. The best way to reach this is to be able to consult databases quickly, to be able to exchange on the practices (What is done elsewhere, what are the consequences).

A tool is at our disposal; it is well-sure the Internet network. There too experiments developed: Sites appeared, of the hospitals installed connections to Internet in the care rooms especially for medical staff. But everything remains to be done so that all the staff can get the best part from it (whether in training or in practice), we also speak about the Intranet which allows a more evolutionary communication and in real time more than the tools classic (e-mail). A new tool is at our disposal, it's to us to use it as efficiently as possible and to set its limits.

\section{ACKNOWLEDGEMENTS}

First, I would like to thank my thesis supervisor and co-author of this paper, for his efforts and help, as well as Professor António Carvalho Brito for his time and advices. Finally, I would like to thank the staff of the Moroccan hospital center for their hospitality and their sense of sharing.

\section{REFERENCES}

[1] ANAP, The National Agency for the Performance Support of Health and medico-social Institutions, piloting performance in the medical social sector: Experimentation of a piloting dashboard, p.12-15, France, 2012.

[2] ANAP, The National Agency for the Performance Support of Health and medico-social Institutions information systems in the medico-social sector: Guide to the use of the diagnostic tool of the maturity of information systems, France, 2013.

[3] C.O. Bagayoko, "Implementation of a Hospital Information System in Francophone Africa: Cinz@n, study and validation of the model in Mali”. Thesis, University of The Mediterranean, 2010.

[4] G. Poncon, "Management of the Hospital Information System: the end of the technological dictatorship". Editions of the National School of Public Health, Paris, p.25, 2000.

[5] J. M. Carroll, "Scenario Based Design: Envisioning work and technology in system development”. New York: John Wiley and Sons, Inc, ed. p.4, 1995.

[6] S. Guetibi, M. El Hammoumi, "Application of Self-Assessment Tool for the Measurement of the Maturity Level of a Moroccan Health Institution by Report to the Quality Approach”. International Journal of Engineering \&Technology IJET-IJENS. 2015a. Vol 15 No 05.

[7] S. Guetibi, M. El Hammoumi, "Development of the hospital information system by one of the eight quality management principles". Oral communication on 1st Edition of the Multidisciplinary International Conference "Becoming a good researcher", 26,27 and 28 March, Tetouan_ Morocco, 2015b.

[8] S. Guetibi, M. El Hammoumi, "Information Systems between Companies and Hospital Institutions: Differences, Common Points and Analyzes SWOT, within the Framework of a Process Approach”, International Journal of Engineering \&Technology IJET-IJENS, 2016. Vol 16 No 02.

[9] V. Andre, P. Fenies, "Modeling and simulation of logistics flows at the Nouvel Hôpital d'Estaing”. Logistics \& Management, 2007. Vol. 15 - No. 1.

[10] WHO, World health organization Everybody's Business: Strengthening Health Systems to Improve Health Outcomes: WHO's Framework for Action. Geneva: WHO, 2007.

[11] WHO, World health organization Management of patient information Trends and challenges in Member States: Based on the findings of the second global survey on e-Health. p. 13-14, 2012.

\section{AUTHOR PROFILE}

Sabrina Guetibi. Born in 03/13/1991 in Fez, she is Moroccan. Sabrina Guetibi is a PhD student in Industrial Engineering at the Sidi Mohamed Ben Abdellah University (USMBA) / Faculty of Science and Technology Fez. She unhooked her Master degree in July 2013; in analysis and quality management at the University Hassan 1 / Faculty of Science and Technology Settat. Miss Guetibi has an Excellence Scholarship (2014 edition) granted by the National Commission on Excellence Scholarships \& National Centre for Scientific and Technical Research. She had the opportunity to be a scholarship holder under the Erasmus Mundus program in university of Porto for one academic year. Her research interests are mainly in Quality Management and Information Systems.

Mohammed El Hammoumi. Professor of higher education at the Sidi Mohamed Ben Abdellah University (USMBA) / Faculty of Science and Technology Fez. He is Head of Department of Industrial Engineering and Director of the Laboratory of Industrial Techniques. He got his doctoral degree in 1994, specializing in Fluid Mechanics at the National Polytechnic Institute of Grenoble. Pr. EL Hammoumi is head of the research team "Tools of decision support in maintenance" and is Instructor in Industrial Engineering technique. 